\title{
Optimally invasive mitral valve surgery: a safe and effective approach
}

\author{
A Amiri, E Delmo Walter ${ }^{*}$, R Hetzer \\ From 23rd World Congress of the World Society of Cardio-Thoracic Surgeons \\ Split, Croatia. 12-15 September 2013
}

\section{Background}

We aim to report our data on the efficacy and safety of using an optimally invasive sternum-sparing approach to MV surgery.

\section{Methods}

Between April 2007 and December 2012, we used a sternum-sparing but optimally invasive approach to MV surgery on 99 patients (mean age $60.71 \pm 12.9$ years) with mean preoperative EF and LVEDD of $53.8 \pm 11.4 \%$ and $56.13 \pm 6.9 \mathrm{~mm}$, respectively. Twenty seven patients had previous coronary artery bypass and MV surgeries. All patients had severe mitral insufficiency (MI) from chordal rupture; prolapse of the anterior leaflet, paravalvular leak, endocarditis, floppy MV, and from previous MV surgery. The optimally invasive approach was a rightsided anterolateral thoracotomy at the 5th intercostal space with an approximately $10 \mathrm{~cm}$ skin incision. Cardiopulmonary bypass (CPB) was through either cannulation of the ascending aorta or femoral artery with direct bicaval cannulation. Modified Gerbode-Hetzer plication for ruptured chordae and modified Paneth-Hetzer posterior annulus shortening annuloplasty, for annulus dilatation or leaflet prolapse were employed. Paravalvular leaks were closed. Intraoperative TEE was used to evaluate the adequacy of repair or replacement.

\section{Results}

The mean CPB and cross-clamp time were $134.4 \pm 52.2$ and $56.63 \pm 29.7$ minutes, respectively. All patients were discharged with either absence or minimal MI. Mean postoperative EF improved to $65.13 \pm 8.7 \%$ while mean postoperative LVEDD decreased to $51.6 \pm 7.0 \mathrm{~mm}$. Sixty-seven percent of patients were extubated within 24 hours, $86 \%$ required minimal postoperative analgesia

* Correspondence: delmo-walter@dhzb.de

Cardiothoracic Surgery, Deutsches Herzzentrum Berlin, Berlin, Germany and all had satisfactory functional results on follow-up (mean $4.2 \pm 1.07$ years) aside from good cosmesis. Freedom of reoperation is $100 \%$ until the last follow-up.

\section{Conclusions}

This new innovative approach is a safe and effective option to MV surgery, reduces surgical trauma, increases patients' functional capacity and satisfaction, no morbidity, with $100 \%$ freedom from reoperation in 4 years.

Published: 11 September 2013

doi:10.1186/1749-8090-8-S1-0269

Cite this article as: Amiri et al:: Optimally invasive mitral valve surgery:

a safe and effective approach. Journal of Cardiothoracic Surgery 2013

8(Suppl 1):0269.
Submit your next manuscript to BioMed Central and take full advantage of:

- Convenient online submission

- Thorough peer review

- No space constraints or color figure charges

- Immediate publication on acceptance

- Inclusion in PubMed, CAS, Scopus and Google Scholar

- Research which is freely available for redistribution
() Bïomed Central
C Biomed Central 